\title{
KUASA HUKUM DI PENGADILAN TATA USAHA NEGARA
}

\author{
REGIF RIO DEWANA \\ regifrio749@gmail.com \\ 1810003600342 \\ UNIVERSITAS EKASAKTI PADANG
}

\section{A.PENDAHULUAN}

Semua pihak yang berperkara pada Pengadilan Tata Usaha Negara (“PTUN") dapat memilih apakah mereka akan didampingi kuasa hukum atau beracara sendiri.

Menurut Pedoman Pelaksanaan Tugas dan Administrasi Pengadilan dalam Empat Lingkungan Peradilan Buku II Mahkamah Agung RI (hal. 825), selain memberikan kuasa kepada advokat,

pemberian kuasa oleh penggugat dapat dilakukan sebagai berikut:

1. penggugat bisa memberikan kuasa insidentil dengan izin Ketua PTUN pada keluarga dengan dikuatkan oleh surat keterangan lurah dan diketahui camat, dan mampu beracara di pengadilan.

2. Biro Bantuan Hukum atau Lembaga Bantuan Hukum dan Fakultas Hukum yang memenuhi ketentuan peraturan perundang-undangan dapat bertindak sebagai kuasa penggugat dalam perkara prodeo.

Sedangkan jika menjadi pihak tergugat, maka pihak tergugat dapat:

1. Memberikan surat kuasa pada advokat; 
2. Memberikan surat tugas tanpa materai kepada Pejabat pada instansi pemerintahan Badan/Pejabat Tata Usaha Negara yang bersangkutan.

3. Jaksa pengacara Negara dapat bertindak sebagai kuasa hukum dari Badan/Pejabat Tata Usaha Negara hanya dalam rangka menyelamatkan kekayaan Negara dan menegakkan kewibawaan pemerintah.

Dengan demikian penyelenggaraan peradilan tata usaha negara di Indonesia merupakan suatu kehendak konstitusi dalam rangka memberikan perlindungan hukum terhadap rakyat secara maksimal.Indonesia sebagai negara hukum tengah berusaha meningkatkan kesejahteraan bagi seluruh warganya dalam segala bidang. Kesejahteraan itu hanya dapat dicapai dengan melakukan aktivitas-aktivitas pembangunan di segala bidang. Dalam melaksanakan pembangunan yang multi kompleks sifatnya tidak dapat dipungkiri bahwa aparatur pemerintah memainkan peranan yang sangat besar. Konsekuensi negatif atas peran pemerintah tersebut adalah munculnya sejumlah penyimpangan-penyimpangan seperti korupsi, penyalahgunaan kewenangan, pelampauan batas kekuasaan, sewenang-wenang, pemborosan dan sebagainya. Penyimpanganpenyimpangan yang dilakukan oleh aparat pemerintahan itu tidak mungkin dibiarkan begitu saja.

\section{B. PEMBAHASAN}

Sebelumnya kami akan menjelaskan mengenai sengketa tata usaha negara dalam Pengadilan Tata Usaha Negara ("PTUN"). Sengketa Tata Usaha Negara adalah sengketa yang timbul dalam bidang tata usaha negara antara orang atau badan hukum perdata dengan badan atau pejabat tata usaha negara, baik di pusat maupun di daerah, sebagai akibat dikeluarkannya keputusan tata usaha negara, termasuk sengketa kepegawaian berdasarkan peraturan perundang-undangan yang berlaku.

[1]Anda tidak menyebutkan apakah Anda sebagai tergugat atau penggugat. Tergugat dalam 
PTUN adalah badan atau pejabat tata usaha negara yang mengeluarkan keputusan berdasarkan wewenang yang ada padanya atau yang dilimpahkan kepadanya yang digugat oleh orang atau badan hukum perdata.

[2] Untuk itu kami akan menjelaskan dari sisi keduanya.

Mengenai Pasal 57 ayat (1) Undang-Undang Nomor 5 Tahun 1986 tentang Pengadilan Tata Usaha Negara sebagaimana telah diubah dengan Undang-Undang Nomor 9 Tahun 2004 tentang Perubahan Pertama atas Undang-Undang Nomor 5 tahun 1986 tentang Peradilan Tata Usaha Negara dan terakhir kali diubah dengan Undang-Undang Nomor 51 Tahun 2009 tentang Perubahan Kedua atas Undang-Undang Nomor 5 tahun 1986 tentang Peradilan Tata Usaha Negara (“UU PTUN”) yang Anda sebutkan, pasal tersebut berbunyi lengkap sebagai berikut: "Para pihak yang bersengketa masing-masing dapat didampingi atau diwakili oleh seorang atau beberapa orang kuasa."

Artinya adalah semua pihak yang berpekara pada PTUN dapat memilih apakah mereka akan didampingi kuasa hukum atau beracara sendiri.

Menurut Adriaan W. Bedner dalam buku Peradilan Tata Usaha Negara di Indonesia (hal. 137), hal ini sesuai dengan prosedur hukum acara perdata yang diatur dalam Het Herziene Indonesisch Reglemen, Staatblad Tahun 1941 No. 44, yang tidak mewajibkan hal ini (harus diwakilkan oleh kuasa hukum)[3].

Pertanyaan Anda adalah apakah kuasa hukum tersebut haruslah advokat yang mengantongi izin advokat?

Menurut Pedoman Pelaksanaan Tugas dan Administrasi Pengadilan dalam Empat Lingkungan Peradilan Buku II Mahkamah Agung RI (hal. 825-826), selain memberikan kuasa kepada advokat, pemberian kuasa oleh penggugat dapat dilakukan sebagai berikut:

1. Penggugat bisa memberikan kuasa insidentil dengan izin Ketua Pengadilan Tata Usaha Negara pada keluarga dengan dikuatkan oleh surat keterangan lurah dan diketahui camat, dan mampu beracara di pengadilan. 
2. Biro Bantuan Hukum (BBH) atau Lembaga Bantuan Hukum (LBH) dan Fakultas

Hukum yang memenuhi ketentuan peraturan perundang-undangan dapat bertindak sebagai kuasa penggugat dalam perkara prodeo.

Lebih lanjut Pedoman Pelaksanaan Tugas dan Administrasi Pengadilan dalam Empat Lingkungan Peradilan Buku II Mahkamah Agung RI (hal. 826) menjelaskan bahwa jika menjadi pihak tergugat, maka pihak tergugat dapat:

1. Memberikan surat kuasa pada advokat;

2. Memberikan surat tugas tanpa materai kepada Pejabat pada instansi pemerintahan Badan/Pejabat Tata Usaha Negara yang bersangkutan.

3. Jaksa pengacara Negara dapat bertindak sebagai kuasa hukum dari Badan/Pejabat Tata Usaha Negara hanya dalam rangka menyelamatkan kekayaan Negara dan menegakkan kewibawaan pemerintah.

Hal serupa juga kami temukan dalam situs resmi Pengadilan Tata Usaha Negara Jakarta, dalam prosedur pengajuan dan biaya perkara dijelaskan bahwa pihak berperkara (penggugat) datang ke Pengadilan Tata Usaha Negara Jakarta (PTUN Jakarta) dengan membawa :

1. Surat gugatan rangkap 8 disertai soft copy gugatannya;

2. Foto copy objek sengketa sejumlah 1 (Satu) eksemplar (apabila sudah ada);

3. Foto copy Kartu Tanda Penduduk (KTP) para pihak sejumlah 1 (Satu) eksemplar;

4. Surat Kuasa sejumlah 5 (Lima) eksemplar disertai foto copy Kartu Pengenal Advokat (Apabila Dikuasakan).

Ini berarti jika Anda sebagai badan/atau pejabat tata usaha negara yang berkedudukan sebagai tergugat, maka dapat saja memberikan surat tugas tanpa materai kepada Pejabat pada instansi pemerintahan Badan/Pejabat Tata Usaha Negara yang bersangkutan. Akan tetapi jika Anda berkedudukan sebagai penggugat, maka legal officer tidak dapat mewakili penggugat jika ia bukan seorang advokat. 
Contoh Putusan

Sepanjang penelusuran kami memang benar ada legal officer yang menjadi kuasa dari sebuah Badan Usaha Milik Negara ("BUMN"), Perusahaan Umum ("Perum”), Sekolah tinggi milik pemerintah yang menjadi tergugat. Namun, kami tidak menemukan perusahaan swasta yang diwakili oleh legal officer yang bukan advokat. Berikut beberapa contoh putusannya:

1. Putusan Pengadilan Tinggi Tata Usaha Negara Jakarta Nomor 87/B/2010/PT.TUN.JKT:

Akhirul Anwar, S.H., Legal Officer Bagian Hukum, menerima kuasa dari Direktur Utama Perum Pegadaian selaku Tergugat.

2. Putusan Pengadilan Tinggi Tata Usaha Negara Surabaya Nomor 74/B/2012/PT.TUN.SBY:

Mohamad Akbar, S.H., selaku Legal Officer, menerima kuasa dari Kepala Kantor Cabang Pacitan PT. Bank Rakyat Indonesia, Tbk (Tergugat I).

3. Putusan Pengadilan Tinggi Tata Usaha Negara Jakarta Nomor 165/B/2013/PT.TUN.JKT:

Muhammad Fazri, S.H., selaku Legal Officer, menerima kuasa dari Ketua Stikes Sari Mulia Banjarmasin (Tergugat).

4. Putusan Pengadilan Tinggi Tata Usaha Negara Medan Nomor: 128/B/2013/PTTUN.MDN:

Idrus Maulana Chatib,S.H. selaku Legal Officer yang menerima kuasa dari PT. Bank Mandiri, Tbk CBC Palembang yang berkedudukan sebagai Tergugat II Intervensi. 
5. Putusan Pengadilan Tinggi Tata Usaha Negara Jakarta Nomor 19/B/2015/PT.TUN.JKT:

Agung Dewandono, S.H. dan Surya Irawan, S.H. selaku Legal Officer, menerima kuasa untuk mewakili PT. Bank Rakyat Indonesia, Tbk yang berkedudukan sebagai Tergugat II Intervensi.

\section{C.PENUTUP}

Berlakunya Undang-undang no.18 tahun 2003 tentang advokat telah menegaskan bahwa advokat yang dapat menjalankan profesinya adalah advokat yang memenuhi syarat-syarat yang ditentukan oleh Undang-undang advokat dan telah mengucapkan sumpah dihadapan Ketua Pengadilan Tinggi di wilayah hukumnya sehingga proceur atau pengacara pokrol bambu tidak dapat lagi diterima untuk beracara di Pengadilan.Pemberian kuasa kepada Kepala/Staf biro hukum,Jaksa selaku pengacara Negaradan kuasa insindentil di Peradilan Tata Usaha Negara harus tetap diterima sepanjangperaturan yang mengaturnya belum dihapus mengingat dasar pemberian kuasa adalahperjanjian/perikatan sehingga orang bebas untuk memberikan kuasanya kepada yangdiinginkannya sepanjang diperbolehkan oleh peraturan perundang-undangan.

Khusus pemberian kuasa insindentil kepada yang masih ada hubungan keluarga sebaiknya diatur secara rinci mengenai batasan hubungan keluarga serta tata cara pemberian izin oleh Ketua Pengadilan Tata Usaha Negara agar tidak digunakan oleh pihakpihak yang mempunyai tujuan lain dari maksud pemberian kuasa. Persoalan adanya perseteruan organisasi advokat yang samasama merasa sebagai organisasi advokat yang syah menurut Undang-undang advokat sebaiknya segera diselesaikan oleh organisasi advokat agar terbentuk wadah tunggal organisasi advokat sebagaimana dimaksud Undang-undang advokat. 


\section{DAFTAR PUSTAKA}

Darmini Roza dan Laurensius Arliman S Peran Pemerintah Daerah Di Dalam Melindungi Hak Anak Di Indonesia, Masalah-Masalah Hukum, Volume 47, Nomor 1, 2018.

Laurensius Arliman S, Komnas HAM dan Perlindungan Anak Pelaku Tindak Pidana, Deepublish, Yogyakarta, 2015.

Laurensius Arliman S, Penguatan Perlindungan Anak Dari Tindakan Human Trafficking Di Daerah Perbatasan Indonesia, Jurnal Selat, Volume 4, Nomor 1, 2016.

Laurensius Arliman S, Problematika Dan Solusi Pemenuhan Perlindungan Hak Anak Sebagai Tersangka Tindak Pidana Di Satlantas Polresta Pariaman, Justicia Islamica, Volume 13, Nomor 2, 2016.

Laurensius Arliman S, Pelaksanaan Perlindungan Anak Yang Tereksploitasi Secara Ekonomi Oleh Pemerintah Kota Padang, Veritas et Justitia, Volume 2, Nomor 1, 2016.

Laurensius Arliman S, Kedudukan Ketetapan MPR Dalam Hierarki Peraturan PerundangUndangan Di Indonesia, Lex Jurnalica, Volume 13, Nomor 3, 2016.

Laurensius Arliman S, Komnas Perempuan Sebagai State Auxialiary Bodies Dalam Penegakan Ham Perempuan Indonesia, Justicia Islamica, Volume 14, Nomor 2, 2017.

Laurensius Arliman S, Peranan Pers Untuk Mewujudkan Perlindungan Anak Berkelanjutan Di Indonesia, Jurnal Ilmu Hukum Tambun Bungai, Volume 2, Nomor 2, 2017.

Laurensius Arliman S, Mewujudkan Penegakan Hukum Yang Baik Untuk Mewujudkan Indonesia Sebagai Negara Hukum, Jurnal Hukum Doctrinal, Volume 2, Nomor 2, 2017.

Laurensius Arliman S, Participation Non-Governmental Organization In Protecting Child Rights In The Area Of Social Conflict, The 1st Ushuluddin and Islamic Thought International Conference (Usicon), Volume 1, 2017.

Laurensius Arliman S, Partisipasi Masyarakat Dalam Pembentukan Perundang-Undangan Untuk Mewujudkan Negara Kesejahteraan Indonesia, Jurnal Politik Pemerintahan Dharma Praja, Volume 10, Nomor 1, 2017, https://doi.org/10.33701/jppdp.v10i1.379.

Laurensius Arliman S, Peran Komisi Perlindungan Anak Indonesia Untuk Mewujudkan Perlindungan Anak, Jurnal Respublica Volume 17, Nomor 2, 2018.

Laurensius Arliman S, Menjerat Pelaku Penyuruh Pengrusakan Barang Milik Orang Lain Dengan Mempertimbangkan Asas Fungsi Sosial, Jurnal Gagasan Hukum, Volume 1, Nomor 1, 2019. 
Laurensius Arliman S, Ilmu Perundang-Undangan Yang Baik Untuk Negara Indonesia, Deepublish, Yogyakarta, 2019.

Laurensius Arliman S, Isdal Veri, Gustiwarni, Elfitrayenti, Ade Sakurawati, Yasri, Pengaruh Karakteristik Individu, Perlindungan Hak Perempuan Terhadap Kualitas Pelayanan Komnas Perempuan Dengan Kompetensi Sumber Daya Manusia Sebagai Variabel Mediasi, Jurnal Menara Ekonomi: Penelitian dan Kajian Ilmiah Bidang Ekonomi, Volume 6, Nomor 2, 2020.

Laurensius Arliman S, Pendidikan Kewarganegaraan, Deepublish, Yogyakarta, 2020.

Laurensius Arliman S, Makna Keuangan Negara Dalam Pasal Pasal 23 E Undang-Undang Dasar 1945, Jurnal Lex Librum, Volume 6, Nomor 2 Juni 2020,

Laurensius Arliman S, Kedudukan Lembaga Negara Independen Di Indonesia Untuk Mencapai Tujuan Negara Hukum, Kertha Semaya Journal Ilmu Hukum, Volume 8, Nomor 7, 2020.

Laurensius Arliman S, Pelaksanaan Assesment Oleh Polres Kepulauan Mentawai Sebagai Bentuk Pelaksanaan Rehabilitasi Bagi Pecandu Dan Korban Penyalahgunaan Narkotika, Jurnal Muhakkamah, Volume 5, Nomor 1, 2020.

Laurensius Arliman S, Aswandi Aswandi, Firgi Nurdiansyah, Laxmy Defilah, Nova Sari Yudistia, Ni Putu Eka, Viona Putri, Zakia Zakia, Ernita Arief, Prinsip, Mekanisme Dan Bentuk Pelayanan Informasi Kepada Publik Oleh Direktorat Jenderal Pajak, Volume 17, No Nomor, 2020.

Larensius Arliman S, Koordinasi PT. Pegadaian (Persero) Dengan Direktorat Reserse Narkoba Polda Sumbar Dalam Penimbangan Barang Bukti Penyalahgunaan Narkotika, UIR Law Review, Volume 4, Nomor 2, 2020, https://doi.org/10.25299/uirlrev.2020.vol4(1).3779.

Laurensius Arliman S, Tantangan Pendidikan Kewarganegaraan Pada Revolusi 4.0, Ensiklopedia Sosial Review, Volume 2, Nomor 3, 2020.

Muhammad Afif dan Laurensius Arliman S, Protection Of Children's Rights Of The Islamic And Constitutional Law Perspective Of The Republic Of Indonesia, Proceeding: Internasional Conference On Humanity, Law And Sharia (Ichlash), Volume 1, Nomor 2, 2020.

Otong Rosadi dan Laurensius Arliman S, Urgensi Pengaturan Badan Pembinaan Idelogi Pancasila Berdasarkan Undang-Undang Sebagai State Auxiliary Bodies yang Merawat Pancasila dalam Perspektif Hak Asasi Manusia, Prosiding Konferensi Nasional Hak Asasi Manusia, Kebudayaan dan Tujuan Pembangunan Berkelanjutan Indonesia pada Masa Pandemi Covid-19: Tantangan untuk Keilmuan Hukum dan Sosial Volume 1, Universitas Pancasila, Jakarta, 2020. 